\title{
Dragonflies (Odonata) Emerging from Brackish Pools in Saltmarshes of Gaspé, Quebec
}

\author{
PaUl M. CATLing
}

170 Sanford Avenue, Ottawa, Ontario K2C 0E9 Canada; email: catlingp@agr.gc.ca

Catling, Paul M. 2009. Dragonflies (Odonata) emerging from brackish pools in saltmarshes of Gaspé, Quebec. Canadian Field-Naturalist 123(2): 176-177.

Enallagma hageni, Lestes disjunctus, Sympetrum costiferum, Sympetrum danae, Sympetrum internum, and Sympetrum obtrusum were observed emerging from brackish pools with an overall salinity range of 6.0-17.3 ppt in three saltmarshes in Gaspé, Quebec. Lestes congener, Libellula quadrimaculata, and species of Sympetrum were prominent among the larvae in these pools.

Key Words: Lestes congener, Libellula quadrimaculata, Sympetrum danae, Odonata, dragonflies, saltmarsh, salinity, Gaspé, Baie des Chaleurs, Quebec.

A recent study (Catling et al. 2006) has shown that saltmarshes are used much more extensively by dragonflies than was previously thought and that the saltmarshes of the Baie des Chaleurs region of Quebec and New Brunswick possess a diverse and distinctive dragonfly fauna. The locations and dominance of restricted saltmarsh flora at the sites included in that study left no doubt that the habitat was brackish, and the observations of emergence, presence of larvae, and large numbers of adults left no doubt as to the utilization of this brackish habitat. However, two of the predominant species, Lestes congener and Sympetrum danae, were not shown definitely to develop in brackish pools. Here presence of larvae and emergence of these and other species from pools of measured salinity are reported.

\section{Methods}

Observations of emergence were made and larvae were collected from saltmarsh pools at three sites (Table 1) in the Gaspé from 16 to 18 July 2009. At all of the sites, the pools were mostly less than $10 \mathrm{~cm}$ deep but up to $30 \mathrm{~cm}$ in the deepest parts and had surrounding and emergent vegetation dominated by Carex paleacea Schreber ex Wahlenb., Juncus spp., and Scirpus spp. The bottoms were organic with an incomplete cover of Chara sp., Ruppia maritima L., and Potamogeton pectinatus L., all of which were confined to patches of deeper water. Salinity was measured with a Pinpoint salinity monitor based on electronic conductance, and the values were converted to
TABLE 2. Species of dragonflies emerging and recorded as larvae from saltmarsh pools at three saltmarshes in the Gaspé.

\begin{tabular}{llll}
\hline \hline & & \multicolumn{3}{c}{ Site } \\
\cline { 2 - 4 } Species & 1 & 2 & 3
\end{tabular}

\section{Emerging}

Enallagma hageni (Walsh)

Lestes disjunctus Sélys

Sympetrum costiferum (Hagen)

Sympetrum danae (Sulzer)

Sympetrum internum Montgomery

Sympetrum obtrusum (Hagen)

\section{Larvae and Exuviae}

Aeshna cf. interrupta Walker

Aeshna cf. umbrosa Walker

Enallagma sp.

Lestes congener Hagen

Lestes $\mathrm{sp}$.

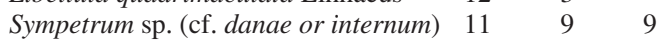

ppt. Identifications of Odonata were made using Walker $(1953,1958)$ and Walker and Corbet (1975). Voucher specimens are deposited in National Collection at Agriculture and Agri-Food Canada in Ottawa (CNC).

\section{Results and Discussion}

Six species, including Enallagma hageni, Lestes disjunctus, Sympetrum costiferum, Sympetrum danae, Sympetrum internum, and Sympetrum obtrusum, were observed emerging from brackish pools with an overall salinity range of 6.0-17.3 ppt (Tables 1 and 2). Libel-

TABLE 1. Names, locations, and salinity range of pools examined in four saltmarshes on the coast of Gaspé.

\begin{tabular}{llcc}
\hline \hline No. & Name & Location & Salinity range (ppt) \\
\hline 1 & Barachois de Malbaie saltmarsh & $48.5829 \mathrm{~N},-64.3015 \mathrm{~W}$ & $8.1-11.0$ \\
2 & Baie au Chêne saltmarsh & $48.0508 \mathrm{~N},-66.6512 \mathrm{~W}$ & $6.0-8.8$ \\
3 & Pointe-à-la-Garde saltmarsh & $48.0754 \mathrm{~N},-66.5430 \mathrm{~W}$ & $16.3-17.3$ \\
\hline \hline
\end{tabular}




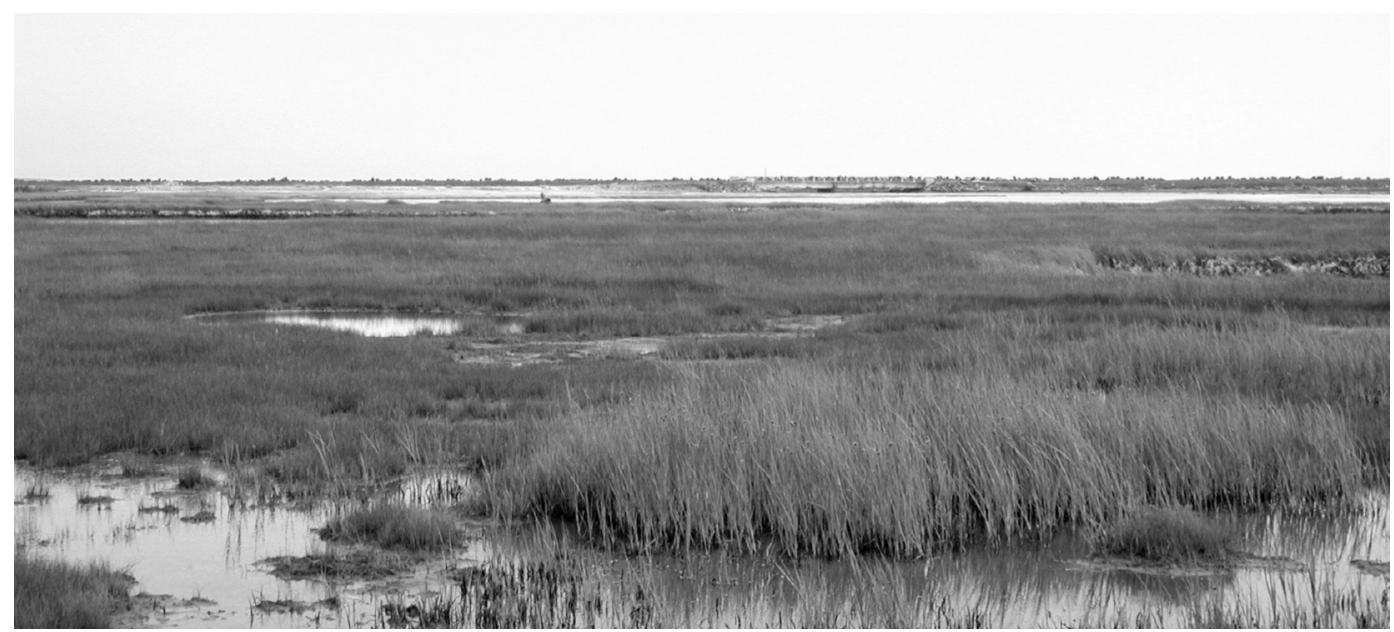

FIGURE 1. Shallow brackish (8.1-11.0 ppt) pools with water to $5 \mathrm{~cm}$ deep and lacking submerged vegetation in the Barachois de Malbaie saltmarsh, where Sympetrum danae and S. internum were emerging and larvae of Lestes congener were present in the pool in the foreground on 17 July 2008. Photo by P. M. Catling.

lula quadrimaculata and Sympetrum sp. were well represented among the larvae from the three sites (Table 2). Larvae of Sympetrum could not be determined with confidence, but most appeared referable to $S$. danae or $S$. internum. Several larvae of Lestes congener found in ponds with salinity ranging from 8.1 to $11.0 \mathrm{ppt}$ were notable and provide support for the suggestion that this species is a resident of saltmarshes in the area (Catling et al. 2006). Other larvae found in the brackish pools included Aeshna cf. interrupta Walker, Aeshna cf. umbrosa Walker, Enallagma sp., and Lestes sp. (Table 1).

All of the species noted above were expected, based on abundance of adults in saltmarshes in the region (Catling et al. 2006), but these observations are of particular interest because they confirm that Lestes congener, L. disjunctus, Libellula quadrimaculata, Sympetrum danae, and S. obtrusum develop in brackish ponds. The observations also provide additional support for use of brackish ponds by the species for which larval records already exist.

Although a comparison of the habitats within pools was beyond the scope of this study, it was noticed that Libellula quadrimaculata larvae were confined to deep- er pools with more submerged vegetation, whereas larvae of Sympetrum and especially emerging Sympetrum danae came from pools less than $10 \mathrm{~cm}$ deep with emergent but no submerged vegetation (e.g., Figure 1).

\section{Acknowledgements}

B. Kostiuk assisted with field work.

\section{Literature Cited}

Catling, P. M., R. Hutchinson, and P. M. Brunelle. 2006. Use of salt marsh by dragonflies (Odonata) in the Baie des Chaleurs region of Quebec and New Brunswick in late summer and autumn. Canadian Field-Naturalist 120: 413420.

Walker, E. M. 1953. The Odonata of Canada and Alaska. Volume 1, Part I: General. Part 2: The Zygoptera-damselflies. University of Toronto Press, Toronto. 292 pages.

Walker, E. M. 1958. The Odonata of Canada and Alaska. Volume 2, Part III: The Anisoptera-four families. University of Toronto Press, Toronto. 318 pages.

Walker, E. M., and P. S. Corbet. 1975. The Odonata of Canada and Alaska. Volume 3: The Anisoptera-three families. University of Toronto Press, Toronto. 308 pages.

Received 15 February 2009

Accepted 27 March 2010 